\title{
System model for physical conditions of road components in Magetan district
}

\author{
Ferro Gadha Gilang Kencana ${ }^{1, *}$, Ary Setyawan ${ }^{2}$, and Syafi ${ }^{2}{ }^{2}$ \\ ${ }^{1}$ Universitas Sebelas Maret Student Program Master of Civil Engineering, Jl. Ir. Sutami 36A, \\ Surakarta 57126. \\ ${ }^{2}$ Universitas Sebelas Maret, Master Program in Civil Engineering, Jl. Ir. Sutami 36A, Surakarta \\ 57126.
}

\begin{abstract}
Road an important component for a region, as well as for Magetan Regency, its position is located at the end of East Java, making the road infrastructure very useful. For this reason, it is necessary to assess the condition of the pavement and the outer side of the pavement and get results. The assessment model of the national road component condition in Magetan district was developed by adopting a condition index system according to the weight and hierarchy of each road component. The weighting of road components using the Analytical Hierarchy Process (AHP) method through questionnaires resulted in the weight of pavement components 0,80 and for the components outside the pavement of 0.20 with the road shoulder sub component having a weight of 0.37 ; drainage channel / edge 0.33; edge slopes 0.15 ; sidewalks of 0.09 and 0.06 and pavement values using the PCI method, where the results of road performance when observed from pavement or out of pavement spawn periodic maintenance.
\end{abstract}

\section{Introduction}

The road is one of the most important infrastructures in supporting the economy and social activities of people, connecting one city to another, between town and village, and between villages. In addition, roads can also increase access to potential areas (tourism, industry, agriculture, fisheries and crops), opening up remote areas and supporting the development of border areas. Another problem faced by local road operators is the absence of a database to accommodate current road condition data and its supporting components and unavailability of road condition assessments related to equipment and limited allocation of funds for road condition surveys. Assessment of road conditions in the area is generally still done visually on the sidewalk and a detailed assessment of the condition of its supporting components. The measured assessment makes it easy for the organizers to get more accurate road conditions data. The availability of a complete database with accurate road condition data and support components will enable the road operator to determine the priority of handling so that the available budget can be targeted. Magetan regency is one of the regencies in East Java Province located on the border of Central Java Province which

* Corresponding author: ferrogadha@gmail.com 
has economic potential in agriculture, fishery, industry and tourism. Magetan Regency crossed national and provincial roads connecting the provinces of East Java and Central Java. Given this condition, good road network management is needed to support community activities so that it is expected to improve the service and community welfare. Most of the national roads in Magetan Regency are in a stable condition but there are some parts of the road that are damaged. This results in reduced comfort perceived by the driver (driving quality) and reduces vehicle speed thus increasing travel time. In addition to unevenness and damage to road surfaces, there is also some damage to other road components such as road shoulders, ditches, sidewalks and equipment that affect the safety of road users and pavement conditions themselves. In this study, pavement component models and external component assessments were developed to evaluate road performance and the priority of national road maintenance handling in Magetan district, which is expected to be an input for policy makers in the implementation of national roads in Magetan district.

\section{Method of use}

\subsection{Weight determination of road components}

Contribution of damage value of each road component on one road weight is not the same. The weight of each component is structured according to the magnitude of the importance of damage to the component in a way, based on the opinions of the competent parties who really master, influence the decision-making or really know the required information. The weighting of road component damage is determined based on its importance because until now there has been no weighting for each of the road components. Pairwise comparisons are often used to determine the relative importance of existing elements and criteria. For each paired comparison criterion an alternative (pairwise comparison) is to compare each element at each level of the hierarchy in pairs so that the importance of the element in the form of qualitative opinion can be found. For quantitative qualitative opinions the assessment scale is used so that the value of opinions will be obtained in the form of numbers (qualitative). Usually the 1 to 9 scale problem is considered the best scale in qualitative opinion, with an accuracy based on RMS (root mean square deviation) and MAD (absolute mean deviation). The value and definition of qualitative opinion on the Saaty comparison scale is shown in Table 1.

Table 1. Values and definitions of qualitative opinion on a comparative scale.

\begin{tabular}{|c|c|c|}
\hline $\begin{array}{c}\text { Level of } \\
\text { Importance }\end{array}$ & Information & Explanation \\
\hline 1 & $\begin{array}{c}\text { Both Elements are the } \\
\text { same (same as Important) }\end{array}$ & $\begin{array}{c}\text { Two elements have the same effect on } \\
\text { purpose }\end{array}$ \\
\hline 3 & is more important & $\begin{array}{c}\text { One element is slightly more important } \\
\text { than the other }\end{array}$ \\
\hline 5 & $\begin{array}{c}\text { important, stronger } \\
\text { important }\end{array}$ & $\begin{array}{c}\text { One element is clearly more important than } \\
\text { the other elements }\end{array}$ \\
\hline 7 & shows its importance & $\begin{array}{c}\text { One element is clearly more important than } \\
\text { the other }\end{array}$ \\
\hline 9 & really more important & $\begin{array}{c}\text { The absolute element is more important } \\
\text { than the other elements }\end{array}$ \\
\hline $2,4,6,8$ & gray area & $\begin{array}{c}\text { The value between the moment of doubt } \\
\text { between two adjacent space values }\end{array}$ \\
\hline
\end{tabular}

Source: Saaty $1998[1,2,6]$ 


\subsection{Weight determination of road components}

\subsubsection{Pavement condition index (PCI)}

Pavement Condition Index (PCI) is an approximate road condition with a rating system to state actual pavement conditions with reliable and objective data. The PCI method was developed in the United States by the US Army Corp of Engineers for airport sidewalks, highways and parking areas, as this method obtained accurate data and estimates of conditions in accordance with conditions in the field. The PCI level is written in levels 0 100. According to Shahin (1994) the sidewalk conditions are divided into several levels such as:

Table 2. PCI values and definitions

\begin{tabular}{|c|c|}
\hline PCI value & Pavement Conditions \\
\hline $0-10$ & Failed (failed) \\
$10-25$ & Very Poor (Very Poor) \\
$25-40$ & Poor (Poor) \\
$40-55$ & Fair (Fair) \\
$55-70$ & Good (good) \\
$70-85$ & Very Good (Very Good) \\
$85-100$ & Excellent \\
\hline
\end{tabular}

Source FAA, 1982; Shanin,1994

The next step is to calculate the PCI value for each sample unit of the road segment, the following will show how to determine the value of PCI:

\section{a. Finding percentage of damage (density)}

Density is the percentage of damage level in the sample area of the unit under review, the density is obtained by dividing the level of damage by the unit sample area. The formula for density values is:

$$
\text { Density }=\boldsymbol{A d} / \mathbf{L d} \times 100 \%
$$

$\mathrm{Ad}=$ Total damage area for each level of damage $\left(\mathrm{m}^{2}\right)$

$\mathrm{Ld}=$ Total length of damage type for each damage level $(\mathrm{m})$

$\mathrm{US}=$ Area of total segment units $\left(\mathrm{m}^{2}\right)$

\section{b. Determining reduced value}

After the density values are obtained, each type of damage is plotted to the graph according to the level.

\section{c. Finding value $q$}

The need to find the value of $\mathrm{q}$ is the value of deduct value. The value of the deduction value is sorted from large to small. Previously check the value of value subtraction by the formula:

$$
M i=1+(9 / 98) *(100-H D V i)
$$

$\mathrm{Mi}=$ Correction value to reduce value

$\mathrm{HDVi}=$ Value that is deducted from the deduction value in one sample unit If all values of the deduct value are greater than the Mi value then the deduct value of the deduct value with the Mi value is performed but if the value of the deduct value is less than the Mi value there is no deduction value of the applied deduct value. 


\section{d. Looking for CDV value}

The CDV value can be sought after the value of $\mathrm{q}$ is known by summing the Deduct Value and then subtracting the sum of the deductive values in the CDV graph according to the $q$ value.

\section{e. Determining the PCI value}

After the CDV value is known, the PCI value can be determined by using the following formula [2]:

$$
P C I=100-C D V
$$

\subsection{Condition value outside the pavement}

The weight of each component outside the pavement is used to calculate the component condition values outside the pavement. The value of the component condition outside the pavement is obtained by summing the sub-component condition value multiplied by the weight of each subcomponent. The composite condition index (CCI) is formulated as follows (Hudson in Wijayanti, 2015):

$$
C C I=W 1 x C 1+W 2 x C 2+W 3 x C 3+\ldots+W n x C n
$$

CCI : Composite index index

W : The weight of the component

C : Conditional value of component content

$\mathrm{N}$ : Number of components

Calculation of component condition values is performed gradually in accordance with the hierarchy of road components, starting from calculating the sub-component condition index for subsequent obtained condition of composite component conditions as follows:

1. Calculating Subcomponent Condition Index (IKSK)

$$
\mathrm{IKSK}=100-\Sigma(\text { correction factor } \mathrm{x} \text { deduction value })
$$

2. Calculating Component Condition Index (CCI)

$$
I K K=I K S K 1 x B S K 1+I K S K 2 x B S k 2+\ldots+I K S K n x B S K n
$$

BSK: Weight of sub component

n : Number of sub components for traffic, located at ground level, below ground and / or water, and above the water surface, except for railroads, lorries and cable roads. Based on the road status is divided into:

a. National Road which is the arterial road and collector road in the primary road network system that connects the provincial capital, national strategic road and toll road.

b. Provincial Road which is a collector road in the primary road network system that connects the provincial capital with the district / city capitals, between regency / municipal capitals and provincial strategic roads.

c. District road which is a local road within the primary road network system that connects the district capital with the sub-district capital, between the sub-district capital, the district capital with the local activity center, between the local activity centers and the 
public road in the secondary road network system within the district and the strategic road district.

d. The Municipal Road, which is a public road in a secondary road network system that connects the centers of urban services, connects the service center to the plot, connects between railroads, and links between settlement centers within the city.

e. Village Road which is a public road connecting the area and / or between settlements within the village, as well as the road environment.

The grouping of roads based on their status aims to bring order and legal certainty of road operation in accordance with the authority of the government and local government. [3]

\section{a. Damage volume and subtracting value}

Determination of component condition value begins by observing the condition of sub components. Observations were made on the type and volume of damage to each sub component. In the assessment of the condition of building components performed by Wijayanti (2013) the value of the deduction of the amount depends on the percentage of damage volume. The reduced value (NP) for each volume range of sub component damage outside the pavement is divided into: minor damage $(0 \%-<25 \%)$ with NP $=25$, moderate damage $(25 \%-<50 \%)$ with NP $=50$ and a heavy workload $(\geq 50 \%)$ with NP $=100$. [5]

\section{b. Correction factor}

Each sub component has a maximum reduction value of one hundred, then for a sub component with more than one type of damage, the deduction value of the type of damage shall be multiplied by a correction factor in order that the total deductible value shall not exceed one hundred. The correction factor used is the weighted value of interest of each type of damage that occurs on each sub component [5]

\section{Research and analysis}

\subsection{Research sites}

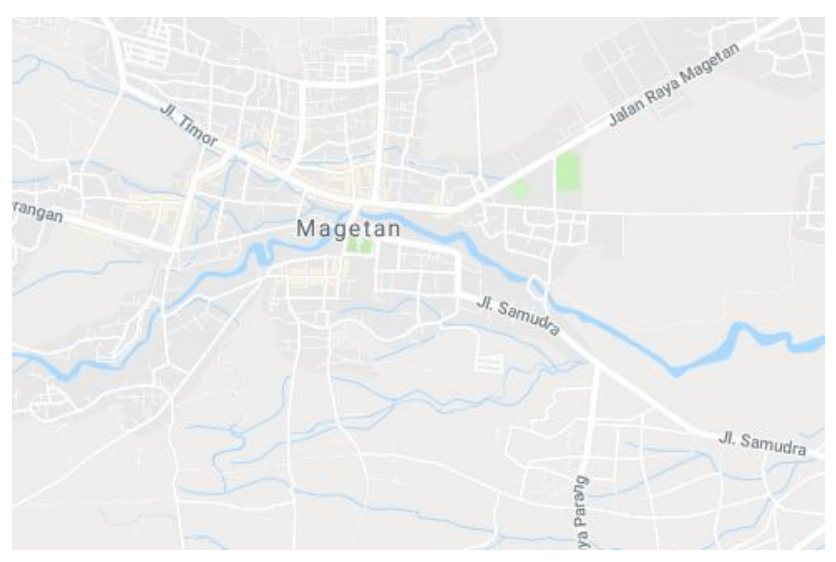

Fig. 1. Maps of magetan district (source: google maps). 
In this study, there are 4-point road in Magetan regency was selected, which is often used by society in driving, to be made object of research, that is:

1. Ahmad Yani Street

2. Dr. Soetomo Street

3. Diponegoro Street

4. Munginsidi Street

\subsection{Data analysis}

\subsubsection{Analysis of pavement}

For data analysis on pavement, using PCI method, observation of each road segment was done to assess the type of its damage, and it was analyzed according to sequence of PCI method formula manually.

\subsubsection{Analysis of outside pavement}

Outdoor pavement analysis using the AHP method requires the respondent or the person giving the score. In this study, the person is from the relevant department in Magetan district. The weight of each condition of the road component and the weight of the damage occurring is determined based on its importance. Determination of weight is done through a questionnaire and is analyzed by Analytical Hierarchy Process (AHP) method which is done in 3 levels (level), they are:

1. Level 1 (goal), which is to evaluate the performance of national road in Magetan District.

2. Level 2 (criteria), which determines the criteria that influence the assessment of national road conditions in Magetan district based on road component condition. The criteria used are the condition of the pavement component (A) and the component condition outside the pavement (B).

3. Level 3 (subcriteria), on the criteria of paved road component subcriteria that is the physical condition of pavement (PFi) while criteria of component condition outside of subcriteria road pavilion which influences physical condition of components outside the pavement (KFi). The determination of sub component weight and damage to components outside the pavement was analyzed in 3 levels, namely:

1. Level 1 (purpose), determining the weight of the sub component and damage to the component outside the pavement

2. Level 3 (criteria), criteria are sub components of components outside the road pavement, which is the road shoulder (B1), edge channel / drainage (B2), edge slope B3, sidewalk (B4) and road equipment (B5).

3. Level 4 (subcriteria), subcriteria is a type of damage to road shoulders, drainage / drainage edges, and damage to road equipment. The influential subcriteria are as follows:
a. Subcriteria of damage to the road shoulder, influential subcriteria: light trail / erosion (B1a), heavy wheel / erosion footprint (B1b), higher than surface 50 road (B1c), lower than road surface (B1d) and required concrete rebound (B1e).
b. Subcriteria of damage to edge drainage, influential subcriteria are: clogged (B2f), eroded (B2g), collapsed B2h), and a rock pair (B2i) is required.
c. Subcriteria for damage to road equipment, influential subcriteria are damage to road signs (B5j), safety fence (B5k), guidance stakes (B5l) and road markings (B5m). [4]




\section{Conclusion}

Based on the results of the analysis and discussion that has been done in the previous chapter, the following conclusions can be drawn:

1. The assessment model of the national road component condition in Magetan district was developed by adopting a condition index system according to the weight and hierarchy of each road component. The weighting of road components using the Analytical Hierarchy Process (AHP) method through questionnaires resulted in the weight of pavement components 0.80 and for the components outside the pavement of 0.20 . In the ponenic component outside the pavement, the road shoulder sub component has a weight of 0.37 ; drainage channel / edge 0.33 ; edge slopes 0.15 ; sidewalks 0.09 and 0.06

2. Results of performance data, priority order and type of maintenance are as follows:

Table 3. Result of performance data.

\begin{tabular}{|c|c|c|c|c|c|}
\hline Name of Street & $\begin{array}{c}\text { PCI } \\
\text { value }\end{array}$ & $\begin{array}{c}\text { Outside } \\
\text { Pavement } \\
\text { Values }\end{array}$ & $\begin{array}{c}\text { Total Physical } \\
\text { Performance of } \\
\text { the Road }\end{array}$ & $\begin{array}{c}\text { List of } \\
\text { Priority }\end{array}$ & $\begin{array}{c}\text { Type of } \\
\text { Maintenance }\end{array}$ \\
\hline Munginsidi St. & 31 & 87.8 & 42.3 & 1 & Periodic \\
\hline Diponegoro St. & 32 & 94.5 & 44.5 & 2 & Periodic \\
\hline Dr. Soetomo St. & 38 & 94.5 & 49.3 & 3 & Periodic \\
\hline Ahmad Yani St. & 40 & 98.2 & 51.6 & 4 & Periodic \\
\hline
\end{tabular}

\section{References}

1. S. Sukirman, Pavement Flexure Highway, Publisher Agency Nova, Bandung, (1995)

2. M. Y. Shahin, Pavement Management for Airports, Roads and Parking Places. Chapman \& Hall. New York, (1994)

3. Directorate of City Road Construction, City Road Maintenance Preparation Procedures (No. 018 / T / BNKT / 1990). Directorate General of Highways Ministry of Public Works. Jakarta, (1990)

4. H. C. Hardiyatmo, Maintenance of Highways, Gajah Mada University Press, Bandung, (2007)

5. N. W. Arief, Performance Evaluation and Maintenance Pattern of Jalan Jenderal Sudirman Salatiga, Sebelas Maret University Surakarta, (2011)

6. Utomo, Suryo Hapsoro Tri, Study of Pavement Condition of Arterial Road in Sleman Regency Using Method of Pavement Condition. Media Technique No. 2nd Year XXIII Issue May 2001. No. ISSN 0216-3012, (2001) 